\title{
Serological Study for Celiac Disease among Sample of Iraqi Patients
} دراسة مصلية لمرض الداء الزلاقي ( حساسية الحنطة) لعينة من المرضى العراقيين

Mohammed Abbas Waheed Amina N. AL-Thwani Mohammed-E-Muhsin* Rabab Kassim*

$$
\begin{aligned}
& \text { Genetic Engineering and Biotechnology Institute/ Baghdad University } \\
& \text { * Iraqi Central Public Health Laboratory } \\
& \text { رباب قاسم الصكر* } \\
& \text { محمد عيسى محسن } \\
& \text { امنة نعمة ثويني } \\
& \text { محمد عباس وحيا } \\
& \text { جامعة بغداد / معهة الهندسة الور اثية } \\
& \text { المختبر المركزي / وزارة الصحة الرحة }
\end{aligned}
$$

E-mail: mhabwe1966@gmail.com

\begin{abstract}
This study aimed to detect the celiac disease by using serological markers including AGA and Ttg. Celiac disease (CD) is a complex small intestinal disorder due to a dysregulated immune response to wheat gliadin in children and adults. A total of $\mathbf{4 1 2}$ suspected patients with celiac disease of males and females with age rang (1-48) year, attended Central Public Health Laboratory (CPHL) Baghdad/ Iraq during the period between December 2015 - April 2016, only fifty patients with celiac disease with age rang 1-40 were confirmed by two serological test which were Anti-gliadin antibodies (AGA) and Anti-Tissue transglutaminase (tTG) conducted by ELISA. The results, showed that $73(17.72 \%)$ of patients were seropositive AGA-IgA, and 83 (20.15\%) were seropositive for AGA-IgG, whereas 67 (16.27\%) were seropositive for both IgA and IgG of AGA test. The seropositive patients for tTG- IgA and tTG -IgG were 60 (14.56 \%), and $69(16.75 \%)$ respectively. The seropositive for both (tTG -IgA and IgG) represented 53 (12.87\%) patient.
\end{abstract}

Keywords: Celiac disease (CD), autoimmune disease, Anti-gliadin antibodies (AGA), Anti-Tissue transglutaminase (tTG), ELISA مرض الداء الزلاقي هو مرض الاضطرابات الهضمية المعقد في الامعاء الدقيقة بسبب الاستجابة المناعية المتفاوتة لكليادين

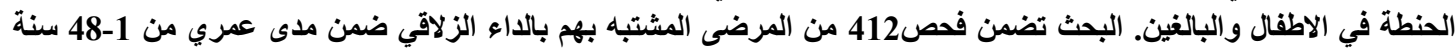

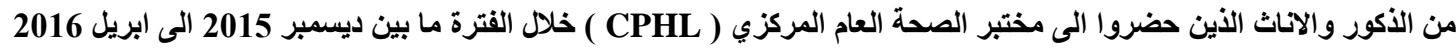
أثبت الاراسة ان خمسين من المرضى فقط يعانون من مرض داث داء الزين الاقي وفقا للفحوصات عن طريق اختبار الاليزا لكلا الفحصين ( tTG و وضمن مدى عمري AGA )

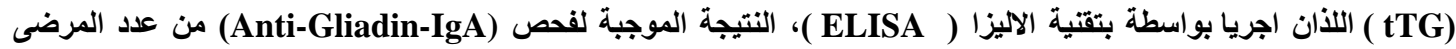

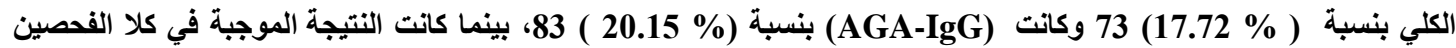

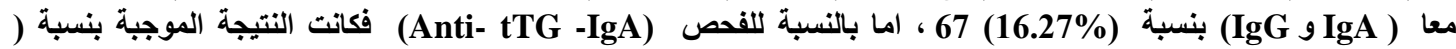

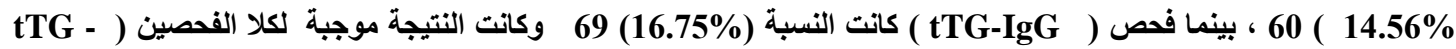
.53 (12.87 \%) بنسبة (IgA and IgG

الكلمات الدالة: الداء الزلاقي، تقتية الاليزا، فحص tTG و AGA

\section{Introduction}

Celiac disease (CD) is a chronic, multiple-organ autoimmune disease that affects the small intestine in genetically predisposed children and adults. It is begun by the ingestion of gluten-containing foods. It is also referred to as celiac sprue [1], gluten-sensitive enteropathy, or nontropical sprue. Celiac disease is caused by a reaction to gluten, which are various proteins found in wheat and in other grains such as barley, and rye [2]. Classic symptoms include gastrointestinal problems such as chronic diarrhea, abdominal distention, malabsorption, loss of appetite, and among children failure to grow normally [3]. The exposure of small intestine to the gluten may lead to the abnormal immune responses and may produce different autoantibodies that can affect a number of different organs [4]. In the small intestine this causes an inflammatory reaction and maybe produces the shortening of the villi lining the small intestine (villous atrophy), this affects the absorption of nutrients, subsequently leading to anemia [5]. As a general rule, the diagnosis of $\mathrm{CD}$ can be established by serological tests, such as: anti-tissue transglutaminase (anti-tTG), Anti-gliadin antibodies (AGA) and anti-endomysium (EMA) auto- 
antibodies, but the confirmation of the intestinal damage depends on the small bowel biopsy and histological analysis [6].

\section{Materials and Methods \\ Patients}

A total of 412 suspected patients with celiac disease of males and females were enrolled in this study, with age ranged 1- 40 year, attended Central Public Health Laboratory (CPHL) Baghdad/ Iraq during the period December 2015 - April 2016.

\section{Samples Collection}

Three milliters of venous blood collected from all subjects under good aseptic precautions using disposable, latex gloves and syringes. The collected blood allowed to clot in serum tube naturally at room temperature, and then separated by centrifugation at $1500 \mathrm{x}$ g for 10 minutes use for serological tests. All samples were labeled by a serial number and the person's name, then immediately frozen at $20^{\circ} \mathrm{C}$.

\section{Serological tests applied for diagnosis of Celiac Disease}

In the current study, only AGA and tTG tests were used experimentally and its results were documented in this work according to the recommendations of North American society in 2013 for the study of CD guideline (NASSCD) [7].

\section{Anti-Gliadin IgA and IgG antibodies}

This test carried out to detect the Anti-Gliadin antibodies type IgA and IgG by ELISA depending on instruction of Manufacture's Company (Immuochem/ Belgium).

Purified gliadin from wheat was bound to microwells. Antibodies against this antigen, if present in diluted serum or plasma, bind to the respective antigen. Washing of the microwells removes unspecific serum and plasma components. Horseradish peroxidase (HRP) conjugated anti-human IgA or IgG immunologically detects the bound patient antibodies forming a conjugate/antibody/antigen complex. Washing of the microwells removes unbound conjugate. An enzyme substrate in the presence of bound conjugate hydrolyzes to form a blue colour. The addition of an acid stops the reaction forming a yellow end-product. The intensity of this yellow colour is measured photometrically at $450 \mathrm{~nm}$. The amount of color is directly proportional to the concentration of $\operatorname{IgA}$ or $\operatorname{IgG}$ antibodies present in the original sample.

- The test is considered positive if the sample result is $>12 \mathrm{U} / \mathrm{ml}$.

- The test is considered negative if the sample result is $<12 \mathrm{U} / \mathrm{ml}$.

\section{Calculation and interpretation of the results}

A standard curve was constructed by plotting the mean absorbance optical density obtained from each standard against its concentration with absorbance value. The concentrations of unknown samples were estimated from the standard curve by interpolation.

\section{Anti-tissue Transglutaminase IgA and IgG antibodies}

This test carried out to detect the Anti-tissue Transglutaminase antibodies type $\operatorname{IgA}$ and IgG by ELISA depending on instructions of Manufacture's Company (Euroimmun / Germany).

The ELISA test kit provides a semiquantitative or quantitative in vitro assay for human autoantibodies of the IgA or IgG class against tissue transglutaminase in serum or plasma. The test kit contains microtiter strip each with 8 break-off reagent wells coated with human tissue transglutaminase. In the first reaction step, diluted patient samples were incubated in the wells. In the case of positive samples, specific IgA or IgG antibodies will bind to the antigens. To detect the bound antibodies, a second incubation was carried out using an enzyme-labelled anti-human $\operatorname{IgA}$ or $\operatorname{IgG}$ (enzyme conjugate) catalyzing a color reaction.

- The test is considered positive if the sample result was $\geq 20 \mathrm{U} / \mathrm{ml}$.

- The test is considered negative if the sample result was $<20 \mathrm{U} / \mathrm{ml}$.

Calculation and interpretation of the results

A standard curve was constructed by plotting the mean absorbance optical density obtained from each standard against its concentration with absorbance value. The concentrations of unknown samples were estimated from the standard curve by interpolation. 
The sensitivity and specificity of the AGA and tTG tests were measured as mentioned by Lalkhen [8], and the outcome clarified that the sensitivity of AGA $94 \%$ while for tTG $80 \%$, and it confirmed that the AGA test more sensitive than tTG test. In contrast the specificity of tTG reached to $95 \%$ more than that of AGA which appeared $90 \%$.

\section{Statistical Analysis}

The Statistical Analysis System- SAS [9] program was used to the show effect of different factors on the study parameters. Chi-square test was used to compare the significance between percentage and least significant difference -LSD test was used to compare the significance between means in this study.

\section{Results and Discussion}

There are many Iraqi studies about celiac disease, such as study of immunological and physiological variables in some pediatric patients with celiac disease conducted by AL-Dulaimi [10] and Serological study of celiac disease among children in Kirkuk city/Iraq conducted by Hameed [11].

\section{Anti-Gliadin IgA and IgG Antibodies test}

The seropositive for both IgA and IgG-AGA were observed in $16.27 \%$ of total patients as presented in Table (1). This finding was higher than the previous Iraqi study done by Hameed [11] which found $13.3 \%$ of patients were seropositive for both $\operatorname{IgA}$ and IgG-AGA. Another study conducted on CD in Sudan recorded higher result reached to $31.3 \%$ seropositive for both IgA and IgG-AGA [12].

Table (1): Seropositive distribution of AGA (IgG and IgA) among Patients group

\begin{tabular}{|c|c|c|c|c|c|c|}
\hline \multirow[t]{2}{*}{ Test } & \multicolumn{2}{|c|}{$\begin{array}{c}\text { Positive AGA } \\
\text { IgA }\end{array}$} & \multicolumn{2}{|c|}{$\begin{array}{c}\text { Positive AGA } \\
\text { IgG }\end{array}$} & \multicolumn{2}{|c|}{$\begin{array}{c}\text { Positive IgA and } \\
\text { IgG }\end{array}$} \\
\hline & No. & $\%$ & No. & $\%$ & No. & $\%$ \\
\hline Positive & 73 & 17.72 & 83 & 20.15 & 67 & 16.27 \\
\hline Negative & 339 & 82.28 & 329 & 79.85 & 345 & 83.73 \\
\hline Total Suspect & 412 & $100 \%$ & 412 & $100 \%$ & 412 & $100 \%$ \\
\hline P-value & $0.0001 * *$ & & $0.0001 * *$ & & $0.0001 * *$ & \\
\hline$* *(\mathbf{P}<0.01)$ & & & & & & \\
\hline
\end{tabular}

The results of this study showed that seropositive IgA-AGA test for total patients was $17.72 \%$ and $20.15 \%$ for IgG-AGA, whereas Al-Dulaimi study [10] got $17.7 \%$ seropositive for IgA-AGA and $18 \%$ for IgG-AGA from 112 patients.

The presence of high titer of AGA of any class whether ( $\operatorname{IgA}$ or $\operatorname{IgG}$ ) was proved to be a positive indicator of $\mathrm{CD}$ but it required further investigation [13].

In AGA test, the sensitivity and specificity of $\operatorname{IgA}$ was marginally superior to that of $\operatorname{IgG}$, but $\operatorname{IgG}$ testing is particularly useful in the $1 \%$ to $2 \%$ of patients with CD who have IgA deficiency [14].

Another study also confirmed that Immunoglobulin G ( $\mathrm{IgG}$ )-AGA was very sensitive but less specific, and IgA-AGA was less sensitive but more specific. It was better to use the combination to give results of a high detection rate [15].

The AGA test used as a single test in diagnosis of CD is not enough in confirming this disease conclusively, even though the test was positive, but if it alone, might be useful test in monitoring the recovering patients with diet therapy [16].

The AGA test was the best test in wide field to monitor the patients' response to keep the regular diet system free of gluten. The measuring of Anti-Gliadin antibodies used as a specific test to detect gluten sensitivity in CD [17]. 


\section{Anti-tissue Transglutaminase (tTG) Antibodies test}

The present study Table (2) found that the seropositive for IgA-tTG was $14.56 \%$, while for IgG-tTG was $16.75 \%$ among 412 of suspected patients. This result slightly higher than previous results who reported that seropositive for IgA-tTG and IgG-tTG were $13.3 \%$ and $15 \%$ respectively [11].

Table (2): Seropositive distribution of tTG (IgG and IgA) among Patients group

\begin{tabular}{|c|c|c|c|c|c|c|}
\hline \multirow[t]{2}{*}{ Test } & \multicolumn{2}{|c|}{$\begin{array}{c}\text { Positive TTG } \\
\text { IgA }\end{array}$} & \multicolumn{2}{|c|}{$\begin{array}{c}\text { Positive TTG } \\
\text { IgG }\end{array}$} & \multicolumn{2}{|c|}{ Positive IgA and IgG } \\
\hline & No. & $\%$ & No. & $\%$ & No. & $\%$ \\
\hline Positive & 60 & 14.56 & 69 & 16.75 & 53 & 12.87 \\
\hline Negative & 352 & 85.44 & 343 & 83.25 & 359 & 87.13 \\
\hline Total Suspect & 412 & $100 \%$ & 412 & $100 \%$ & 412 & $100 \%$ \\
\hline$P$-value & 0.0001 & $* *$ & 0.0001 & $* *$ & 0.000 & \\
\hline
\end{tabular}

The results showed that the seropositive of both $\operatorname{IgA}$ and $\operatorname{IgG}$ were for $12.87 \%$ among 412 of suspected patients, and this result was higher than the previous Egyptian study which found both IgA and IgG tTG were positive in $4.7 \%$ among 150 suspected patients with CD [18]. Another study showed both of them were positive in $6 \%$ among 350 suspected patients with CD [19].

The IgG-tTG test has been known as a research tool since 2000. It has not clinically widespread used but would be useful for patients with IgA deficiency to screen them for CD [20]. Studies in pediatric populations confirmed the high specificity of immunoglobulin A (IgA) tTG antibodies in the diagnosis of $\mathrm{CD}$ [21].

Previous study found that high levels of IgA-tTG and IgG-tTG antibodies which were associated with the grade of mucosal villous atrophy and a more severe in clinical presentation, and if combined IgAtTG and IgG-tTG tests would enable a noninvasive prediction of small intestinal villous atrophy with high accuracy, and might reduce the need for a biopsy in patients with suspected CD [22].

Tissue transglutaminase represents the predominant, if not the sole, and considered characteristic for CD. Gliadin is a preferred substrate for tissue transglutaminase and the interaction of gliadin and transglutaminase may result in the creation of new antigenic complexes [23].

Some studies proved that anti -tTG antibodies test was more superior than AGA test [24], but other researchers reported that AGA was more commonly used [25]. Usually Anti -Gliadin antibodies test was considered less specific and more sensitive than anti-tTG antibodies [26].

References

1. Julio, C., Carolina, C. and Gino, Roberto, C. (2016). Celiac disease World Gastroenterology Organization Global Guidelines (WGO). Gut, J.; 62(1): 43-52.

2. Tovoli, F., Masi, C., Guidetti, E., Negrini, G., Paterini, P. and Bolondi, L. (2015). Clinical and diagnostic aspects of gluten related disorders. World Journal of Clinical Cases: WJCC, 3(3), 275.

3. Fasano, A. (2005). Clinical presentation of celiac disease in the pediatric population. Gastroenterology, 128(4), S68-S73.

4. Lundin, K. E., and Wijmenga, C. (2015). Coeliac disease and autoimmune disease [mdash] genetic overlap and screening. Nature Reviews Gastroenterology \& Hepatology, 12(9), 507-515.

5. Vivas, S., Vaquero, L., Rodríguez-Martín, L. and Caminero, A. (2015). Age-related differences in celiac disease: Specific characteristics of adult presentation. World journal of gastrointestinal pharmacology and therapeutics, 6(4), 207.

6. Villanacci, V., Ceppa, P., Tavani, E., Vindigni, C. and Volta, U. (2011). Coeliac disease: the histology report. Digestive and Liver Disease, 43, S385-S395. 
7. North American society study of celiac disease (NASSCD). (2013).

8. Lalkhen, A.G. and McCluskey, A. (2008). Clinical tests: sensitivity and specificity. Continuing education in anaesthesia, critical care and pain, 8(6), 221-223.

9. SAS. (2012). Statistical Analysis System, User's Guide. Statistical. Version 9.1th ed. SAS. Inst. Inc. Cary. N.C. USA.

10.AL-Dulaimi, N. (2011). studying some immunological and physiological variables in some pediatric patients with celiac disease. Master thesis. College of science. University of Anbar.

11. Hameed, B. (2012). Serological study of celiac disease among children in Kirkuk city/Iraq. Master thesis. College of Health and Medical Technology. University of Baghdad.

12. Mohammed, I., Karrar, Z. and El-Safi, S. (2006). Celiac disease in Sudanese children with clinical features suggestive of the disease. Eastern Mediterranean Health J.; 12(5): 582-589.

13. Markku, M., Kirsi, M., Jorma, K., Petri, Kulmala., Mila, H. and Tuomo Karttunen, M. (2003). Prevalence of Celiac Disease among Children in Finland. N Engl J. Med; 348(19):2517-2524.

14. Hadzise, K., Karny, R. and Nusslé, M. (2014). Endomysium and gliadin IgA antibodies in coeliac disease. I.J.IMS; 6(21); 735-44.

15. Misra, S. and Ament, M. E. (1995). Diagnosis of coeliac sprue in 1994. Gastroenterology clinics of North America, 24(1), 133-143.

16. Trier, J. (1998). Diagnosis of celiac sprue. Gastroenterology J. 115(1):211-216.

17. Rostom, A., Murray, J. A. and Kagnoff, M. F. (2006). American Gastroenterological Association (AGA) Institute technical review on the diagnosis and management of celiac disease. Gastroenterology, 131(6), 1981-2002.

18. Abu-Zekry, M., Kryszak, y., Diab, M. and Catassi, C. (2008). Prevalence of Celiac Disease in Egyptian Children Disputes the East-West Agriculture-dependent Spread of the Disease. J. Pediatric. Gastroenterol. Nutr; 47(4): 136-140.

19. Emami, M., Karimi, S., Kouhestani, S., Hashemi, M. and Taheri, H. (2008). Diagnostic Accuracy of IgA anti-Tissue Transglutaminase in Patients Suspected of Having Celiac Disease in Iran. J. Gastro intestine Liver Dis.; 17(2): 141-146.

20. Korponay-Szabo, I., Dahlbom, I., Laurila, K. and Koskinen, S. (2003). Elevation of IgG antibodies against tissue transglutaminase as a diagnostic tool for celiac disease in selective IgA deficiency. Gut J.; 52(4): 1567-1571.

21. Hojsak, I. and Shamir, R. (2011). Tissue transglutaminase antibodies in celiac disease: focus on the pediatric population. Drugs of today (Barcelona, Spain: 1998), 47(9), 683-691.

22. Dahlbom, I., Korponay-Szabo I., Kovacs, J. and Szalai, Z. (2010). Prediction of clinical and mucosal severity of celiac disease and dermatitis herpetiformis by quantification of $\operatorname{IgA} / \mathrm{IgG}$ serum antibodies to tissue transglutaminase. J. Pediatr. Gastroenterol. Nutr; 50(6): 140-146.

23. Dieterich, W., Ehnis, T., Bauer, M., Donner, P., Volta, U., Riecken, E. and Schuppan, D. (1997). Identification of tissue transglutaminase as the autoantigen of celiac disease. Nat. Med. J.; 3(3): 797-801.

24. Sulkanen, S., Halttunen, T. and Launila, K. (1998).Tissue transglutaminase autoantibody enzyme-linked immunosorbent assay in detecting celiac disease. Gastroenterology J.; 115(7): 1322-1328.

25. Giersiepen, K., Lelgemann, M., Stuhldreher, N., Ronfani, L., Husby, S., Koletzko, S., Korponay, S. and Ilma, R. (2012). Accuracy of Diagnostic Antibody Tests for Coeliac Disease in Children; J Pediatric Gastroenterol Nutr. 54 (2): 229-241.

26. Rostom, A., Murray, J. A. and Kagnoff, M. F. (2006). American Gastroenterological Association (AGA) Institute technical review on the diagnosis and management of celiac disease. Gastroenterology, 131(6), 1981-2002. 